\title{
African Trading Post in Guangzhou: Emergent or Recurrent Commercial Form?
}

\author{
Sylvie Bredeloup \\ UMR Laboratoire Population Environnement et Développement (LPED), Marseille, France \\ Sylvie.Bredeloup@univ-provence.fr
}

\begin{abstract}
In the early 200os, nationals of Sub-Saharan Africa who had settled in the market places of Hong Kong, Bangkok, Jakarta, and Kuala Lumpur, moved to Guangzhou and opened offices in the upper floors of buildings in Baiyun and Yuexiu Districts. These were located in the northwest of the city, near the central railway station and one of the two fairs of Canton. Gradually these traders were able to create the necessary conditions of hospitality by opening community restaurants on upper floors, increasing the number of showrooms and offices as well as the services of freight and customs clearance in order to live up to an African itinerant customer's expectations. From interviews carried out between 2006 and 2009 in the People's Republic of China and in Hong Kong, Bangkok, Dubai, and West Africa, the article will first highlight the economic logics which have contributed to the constitution of African trading posts in China and describe their extension from the Middle East and from Asia. The second part will determine the respective roles of migrants and traveling Sub-Saharan entrepreneurs, before exploring their interactions with Chinese society in the setting up of these commercial networks. It will also look at the impact of toughening immigration policies. It is the principle of the African trading posts of anchoring of some traders in strategic places negotiated with the host society that allows the movement but also the temporary settlement of many visitors. The first established traders purchase products manufactured in the hinterland to fulfill the demand of the itinerant merchants who in turn supply customers located in other continents.
\end{abstract}

\section{Keywords}

trading post, African migration, African entrepreneurs, Guangzhou

\section{Résumé}

Au début des années 2000, des ressortissants d'Afrique Sub-saharienne qui s'étaient installés dans les places marchandes de Hong Kong, Bangkok, Jakarta, et Kuala Lumpur, se sont déplacés vers Guangzhou. Ils ont ouverts des bureaux aux étages supérieurs de tours situées dans les quartiers de Baiyun et de Yuexiu, au nord-ouest de la ville, près de la gare ferroviaire principale et d'une des deux foires du Canton. Progressivement, ces commerçants ont réussi à créer les conditions d'hospitalité en ouvrant des restaurants communautaires et en augmentant le nombre de showrooms et de bureaux, tout comme les services de fret et de dédouanement, en vue de satisfaire les 
attentes des clients itinérants africains. À partir d'entretiens réalisés entre 2006 et 2009 en République Populaire de Chine, ainsi qu’à Hong Kong, Bangkok, Dubaï, et en Afrique de l'Ouest, l'article va d'abord mettre en lumière les logiques économiques qui ont contribué à la constitution de comptoirs commerciaux africains en Chine, et décrire leur extension à partir du Moyen-Orient et de l'Asie. La seconde partie examinera les rôles respectifs des migrants et des entrepreneurs subsahariens itinérants, avant d'explorer leurs interactions avec la société chinoise, dans l'installation de ces réseaux commerciaux. Nous observerons également les effets du durcissement des politiques d'immigration. C'est l'ancrage des commerçants africains en des pointss stratégiques négociés avec la société d'accueil, qui permet le mouvement, mais aussi l'installation temporaire de nombreux visiteurs. Les premiers commerçants installés se procurent des produits manufacturés dans l'arrière-pays, afin de satisfaire la demande des marchants itinérants qui, à leur tour, approvisionnent une clientèle située sur d'autres continents.

Mots-clés

comptoir commercial, migration africaine, entrepreneurs africains, Guangzhou

In the context of a neo-liberal market, the recent arrival of Chinese nationals in Sub-Saharan Africa has contributed to the reshaping of import chains and to a redefinition of the role of both Chinese and African traders in a transnational commercial system. Their routes intertwine. Their destinies become tangled while global competition is exacerbated. For many observers, African businessmen only started to come and buy directly from the source in mainland China about ten years ago. But our own research ${ }^{1}$ has shown that older and more discreet dynamics emerged as early as the mid-1980s, stressing the capacity of African traders to anticipate change by expanding their networks into Asia. In the absence of oil contracts or construction sites, transactions deal primarily with consumer goods manufactured in China and exported to Africa by African merchants.

Our discussion will aim to account for the emergence of the economic mechanism that contributes, to some extent, to the restructuring of relations between China and Africa, and to assess the forms that are reminiscent of

1) About 50 African migrants (settled storekeepers and visitors) were interviewed in Guangzhou in Baiyun and Yuexiu districts; some were repeatedly interviewed over two years and in different working situations. Additional interviews were carried out in Bamako and Dakar with the family members of migrants settled in Asia. Interviews were also conducted in Guangzhou with the people in charge of associations of Ghanaian, Guinean, Malian, Nigerian, Nigerien, and Senegalese migrants. Other people in charge of associations (Guinea, Mali, and Nigeria) were also asked questions in Bangkok (Bangrak and Sukhumvit districts) and Hong Kong. Discussions were also conducted with Arab traders and Chinese interpreters in Guangzhou and Hong Kong (Kowloon). But the latter remained reserved, perhaps surprised by my familiarity with African migrants. 
maritime trading posts in Ancient Times. First, it will reconstruct the various stages of migration to explain the spread of African traders ${ }^{2}$ further east before highlighting the many migrant figures - traders, intermediaries and travelers who structure the marketplace. Thirdly, we will explain how their presence in a particular Guangzhou district can disrupt the current local behaviors and we will examine the professional relation to the 'Other,' knowing that the room for maneuver of the traders has been reduced by the recent Chinese competition targeting such sectors and by the toughening of immigration policies.

\section{Interconnected Marketplaces}

In a way, the African trading post is a combination of the Greek colony and Zongo. Created respectively at the initiative of and for the benefit of foreigners, these organizations are based on an agreement between producers and sellers. Established by the colonists, the emporion is structured around a port and works as a foreign enclave working in close collaboration with the hinterland. The antique trading post's main objective is to sell goods produced on the colonized land and to circulate them (Braudel 1949; Tarrius 1995). On the other hand, the Zongo is structured in some cities in sub-Saharan Africa (Togo, Benin, Ghana, and Nigeria) to accommodate the original temporary foreign Muslim merchants traveling long distances. Initially a rest area for itinerant merchants, the Zongo became by extension the area reserved for foreigners, gradually allowing craftsmen, workmen, and merchants (Cohen 1969; Agier 1983). Like the Zongo, the trading post cannot be regarded as an enclave from the market since it is visited by an increasingly heterogeneous population, including a high proportion of national residents.

Two economic logics have contributed to the construction of African trading posts in China. Initially, in the middle of the 1980s, it was precious stones that were the basis of trade networks between Africa, Europe, and Asia. They

\footnotetext{
2) There is no census of African communities in the PRC; however, according to a report written in 2007 by 'The Border Administration Office of Guangzhou', there were about 500,00o foreign visitors in transit in the capital of Guangdong and 15,000 foreigners residing in the city. According to Chinese researchers, there were just over 1,00o African traders in Guangzhou and nearly 32,00o African visitors identified in hostels and restaurants in the city ( $\mathrm{Li}, \mathrm{Xue}$, Lyons, \& Brown, 2007). According to journalistic sources there are more than 120,000 Africans permanently living in Guangzhou (Les Echos August 13th 2008). My own research has shown the recent increase in illegal migration, departures related to the strengthening of police control, and finally the porosity of the status of migrants. It is therefore difficult to establish accurate estimates.
} 
allowed the mainly Malian and Guinean traders to get a foothold in Asian cities. $^{3}$ A significant number of them permanently settled in Bangkok, around Royal Plazza Building, ${ }^{4}$ since the progressive implementation of the Schengen Agreement made the entrance of smugglers to Germany as well as the flow of the rough stones more difficult. Two hundred and fifty African families live in Bangrak district at the moment. As intermediaries paid on a commission basis, the wholesalers continue to source precious and semi-precious stones (sapphire, aquamarine, and tourmaline) in Africa (Nigeria, Zimbabwe, Zambia, DRC, Madagascar, South Africa etc.) that they sell in Bangkok or in jewel fairs (Hong Kong and China) with Asian and European buyers. From these posts, some of them later decided to canvass safer markets. Thus based on gold and precious stone trading between the Central African Republic, Brussels and Bangkok, a national from Nioro (Mali) has found the means to expand his activities. Not only is he investigating other Asian countries (Indonesia and Hong Kong), offering his rough stones to new cutting centers, but he has also been trying to import African wood and fruit, and to export clothing to Central Africa. As the situation became worse in Southeast Asia with the rise of the financial crisis, he was the first to set up an office in Guangzhou in 2000 to export essentially Chinese goods of all kinds to Africa.

More recently, the second logic led African traders who had until then moved from the Black Continent to Dubai - the world's re-exportation platform of Chinese products - to go right to the very source of the supply chain in China's Special Economic Zones. In the gos, Dubai offered cheap warehouses and competitive infrastructures and connections with the whole world. Ten years later, China was able to propose direct air connections to the African continent. As a result Addis Ababa and Nairobi became, within a couple of years, well-known hubs for African businessmen wanting to go to Guangzhou via routes to the PRC opened by the Ethiopian and the Kenyan airlines. Among Sub-Saharan Africans, Malians and Nigerians were the first to move to places of production to reduce costs by minimizing intermediate expenses. Several traders established in Guangzhou and Hong Kong said that the Chinese had long marketed wax ${ }^{5}$ from their own factories close to Lagos and Kano in Nigeria before producing and printing similar fabrics in their own country.

3) My previous research allowed me to locate the commercial routes set up by West African diamond dealers from Senegal, Mali, Mauritania, and Gambia from independence onwards.

4) About ten interviews were held with Malian, Guinean, and Gambian traders in precious and semi-precious stones in Bangkok, in Bangrak district (July 2008).

5) Dyed fabric whose designs are inspired by Javanese batik. These pieces of cotton mainly for African customers were first printed by Dutch and British companies before being manufactured in Africa. 
African tradesmen moved from one marketplace to another depending on the comparative advantages that they encountered here and there: large-scale harbor and airport facilities, adapted hotel equipment, and connection to a hub of successful enterprises in the hinterland. They also took into account the migratory policies applied by the different states, thus creating in their own way new city networks. In Bangkok, where industry boomed in the late 1980s (Gemdev 1997), they visited local factories to have cosmetic and textiles for the African market manufactured. This was the time when famous brands such as Levi Strauss had their jeans manufactured before numerous workshops copied them on a mass scale. In Jakarta, they purchased supplies of synthetic fabrics. The Indonesian capital became a secondary market for African storekeepers before the xenophobic acts of 1988 against Chinese merchants and other foreigners. This was a time when economic and financial crises led to a questioning of their presence (Izraelewicz 2005). From Thailand, where the baht collapsed and led to the country's bankruptcy, the Asian crisis spread to Southeast Asia and Japan. The region saw slumping currencies, devalued stock markets and a precipitous rise in private debt. In Thailand as well as in Indonesia, where Chinese control over the national economy was supremely important and where anti-Chinese xenophobia was rife, the financial crisis exacerbated racist behavior (Rigg 2003). In this turmoil, African traders decided to explore new markets, and expanded from the Hong Kong metropolis into the People's Republic of China (Bodomo 2006). Endowed with a truly modern transport infrastructure, this financial center and 'global city' came to assume the role of gateway to China for African entrepreneurs canvassing factories in Shenzhen's special zone (Bertoncello 2009).

They reached Guangzhou by rail, and although it did not have port outlets as efficient as Hong Kong's, it did nonetheless offer cheap, lower quality products through its 9oo-plus wholesale markets. The context was favorable: the PRC had only just entered the World Trade Organization (in December 2001) and had started to open its doors to foreign investors. The province of Guangzhou now represents more than $30 \%$ of the annual exports of China. A third of all exports are negotiated at the Guangzhou fair which takes place twice a year. But while the situation toughens again for foreigners in Guangzhou, some African merchants take the northeasterly road to Yiwu, now considered the largest export center of daily consumer goods in the world (Lin 2006; Pliez 2007). Consisting of a series of wholesale markets, it extends over an area of approximately one million square meters. Other merchants travel to Bangkok or Hong Kong, thereby demonstrating great flexibility in adapting to the situation. Some even venture to Vietnam or India, aware as they are of the 
deteriorating working conditions. Downstream on the African continent, the trading posts assume the presence of outposts from which the bonded goods manufactured in factories destined for a mainly African clientele can be moved to more remote areas. Some traders, well established in China, have therefore set up bonded relays in Lomé and Nairobi. A new transnational African business network is emerging in Asia, and has the capacity to flood Sub-Saharan Africa with low-cost goods.

\section{Traders and Itinerant Migrants: A Multiplicity of Figures}

The principle of the African trading post is the anchoring of some merchants in strategic places negotiated with the host society that allows both the movement and temporary settlement of visitors. The first established tradesmen tap products manufactured in the hinterland to fulfill the demand of itinerant merchants supplying customers in Africa. Beyond their social, cultural, and geographical heterogeneity, these traders share the same values and a system of trust based on giving one's word in transactions. The trading posts suppose that sedentary traders are the new bridgeheads of Sub-Saharan migration to China. They discuss their settlement with local society, they use different local, regional, national, and international laws and adapt to the reception conditions offered to them. When their fellow countrymen encounter difficulties with the Thai, Dubai, or Chinese authorities because of their illegal situation, they play the role of honorary consuls or get in touch with lawyers to get people out of jail. In short, they make the administrative steps of their compatriots waiting to launch themselves into the import-export business easier. Through these practices, the traders summon the traditional functions of hospitality perpetuated by long-distance African Muslim merchants since before colonization. The njaatigue (in Bambara language), who is both the landlord and an intermediary, provides lodging and represents itinerant traders before the authorities. He also becomes a guarantor among buyers and sellers, and sometimes takes responsibility for book-keeping or interpreting. Trust and obligations depend on patterns of kinship magnified by Islamic precepts. Hill (1966) and Cohen (1984) emphasized this landlord system of trade in West Africa which was associated with long-distance northern Muslim traders. In his work on Hausa migrants in Nigeria, Cohen introduced a difference between 'the settlers,' 'the migrants,' and 'the strangers' while showing that these three categories were not mutually exclusive. Hausa migrants worked as itinerant traders with a very small capital in Yoruba towns where inhabitants considered 
them permanent settlers. They were often house-owners, lived with their families, and engaged 'in occupations which necessitate long experience in local affairs and wide connections in the host city'. 'Strangers,' visitors, or 'transients' came to stay temporarily, selling or buying goods. 'Strangers are the customers, who are served by settlers and are in fact the source of livelihood for the settlers' (Cohen 1984: 37). Just like in Guangzhou, in Yoruba cities there was fluidity in the status of 'migrant.' This evasive figure was not unlike that of Middleman Minorities, these intermediaries located in a foreign country and benefiting from their transnational networks and interpersonal skills to facilitate links between buyers and sellers (Bonacich 1973). They were tricksters who had to use their experience as city-dwellers to adapt to the demand and find their place in the host society, combining their various skills (linguistic, professional, relational, and religious) as needed.

\section{Traders: Profiles and Careers}

In Asia, African merchants were renamed 'traders.' In this context, this term designates a commercial operator who carries out the wholesale of manufactured goods. He constantly adapts to consumer demand by directly canvassing factories to come up with better suited products. The trader is able to create his office or his trading company because on the one hand he has obtained a working visa or a long-term residence permit, and on the other hand, he has successfully transferred to the Guangzhou branch what was located in his home country or elsewhere (Thailand and Indonesia) after the company was recognized by the Chinese authorities. Providing the interface between suppliers and vendors, he offers a broad range of services (bargaining, warehousing, transit, customs clearance, interpretation, NICT ...) to his African clientele. He opens branches in Lomé, Nairobi, or Addis Ababa for those who cannot travel to Asia. If these traders can export goods manufactured in Asia, the current Chinese legislation, unlike that which was effective in Hong Kong, does not allow them to import products from African farming. They cannot, therefore, offer services as competitive as those of Chinese traders since the latter are increasingly present in Africa, where they open shops in the center of African cities to sell Chinese goods (Bertoncello and Bredeloup 2007; Bertoncello 2009).

When their fellow countrymen encounter difficulties with the Chinese authorities because of their illegal situation, African traders intervene on their behalf. Thus Mr. H., responsible for the Nigerien community, said: 'Every day there are problems: people who lose their money and visitors who do not know 
how to resolve their disagreements with their suppliers, so I am Mr. Fix-It slightly better, a problem solver.' ${ }^{6}$ These traders also exhibit social characteristics typical of the middlemen minorities described by Bonacich: residential segregation, schools in their own language, and a lack of political involvement. Specialized in certain activities, often trade, these 'ethnic minorities' play an intermediary economic role and tend to act as sojourners without planning to settle permanently. But despite these successes in linking up Chinese producers with African or European traveling sellers, they also struggle to reinforce their position as middlemen minorities in a local society with a strong labor division between the dominant productive elite and the minority of customers.

Several generations ${ }^{7}$ of traders live and work side by side: the oldest, from Mali and Guinea, often polyglot but illiterate, have made lifelong careers in trading, stretching the migratory stopovers across the world. The youngest, from West or Central Africa, arrived later. They had often completed university or professional courses in China as well as in Europe, the Maghreb, or the United States. Some of them arrived as students in the 1990s in the context of cooperation programs, and decided to stay after graduating from a Chinese university. They worked as interpreters for export companies or the Guangzhou commercial Fair before opening their own agencies. But these categories are porous. Some of these storekeepers probably work together, but most of them treat their business as individual or familial operations, and competition among them does exist. They share their experiences within the associations they created, which are aimed at building a community capable of withstanding Chinese competition and of negotiating further advantages with the local authorities. Yet the lack of degrees is a significant obstacle. The better educated among them, those who master the Chinese language as well as their illiterate fellow countrymen, seem more able to deal with high technology products from their Chinese suppliers. Some stated that their engineering degree had allowed them to position themselves in very specific niches and to be introduced to the local authorities. They took the time to weave networks in several Asian countries and to sharpen their withdrawal strategies. Arrived more recently, young graduates give priority to relations with the Chinese suppliers, taking advantage of their technical and linguistic knowledge to obtain more exclusive markets at the best price. There is no evidence, in fact, that the educational level of the traders significantly affects their management of companies. With or without a degree, many work with a member of their family, which generates

6) Interview conducted in Guangzhou, July 172008.

7) This term refers both to age and to the timeline of arrival in China. 
an informal human resources management. It is difficult, on the other hand, to establish how differences in national origin impact the commercial dynamics. The traders maintain preferential links with visitors from their country of origin. They also work in European countries such as Italy, Spain, and Arab countries such as Saudi Arabia, Algeria, and Morocco, intervening in the market for a broad range of nationalities. A significant distinction however is to be noted: nationals from French-speaking countries stock up preferentially with traders from Mali, Guinea, or Senegal while the Ghanaians and the Nigerians first and foremost deal with the large storekeepers from the English-speaking zone. This linguistic partition may change as French-speaking African traders increasingly master English (Bodomo 2010). They already have visitors from East Africa and should be able to attract an English-speaking clientele, provided they invest in highly specialized markets such as veterinarian products.

Belonging to the former category, Mr. D, 8 a Malian national, became the first 'Sahelian' to set up his trading business in Guangzhou in 2000. Hawking cigarettes in the streets of Bamako when growing up, he launched himself into the ready-to-wear business in Cameroon and Gabon and into the precious stones traffic between Tanzania, Madagascar, and Bangkok and Hong Kong. At the time of this perilous trade, with other African diamond merchants, he learnt the import-export business in anticipation of the future. In the producer countries, where the political climate is often unstable and food shortages common, precious stones are rarely exchanged for money and are instead bartered for various goods, at the whim of circumstance (Bredeloup 2007). Before coming and canvassing in China, Mr. D had already set up import-export activities, opening offices in Jakarta and Bangkok which were connected with Togolese and Ethiopian outposts. Taking advantage of the Canton Fair, he came to prospect the region in 1998, wishing to benefit from the commercial opening up of China to find a new direction for his business. He set up shops in Guangzhou in 2000, convinced that his clientele would follow and that his trading would only expand in connection with the commercial opening of the PRC. While he closed his offices in Jakarta and Bangkok, he kept open those in Lomé and Dar Es-Salaam to ground his presence on the African continent. Today, Mr. D is considered by the African communities and Chinese interpreters to be Guangzhou's major West African merchant, exporting a large range of manufactured products, from electric toothbrushes to DVD drives, plastic sandals and green tea. 'When an African, American, or European client arrives at my company, he can see the clothing samples, hardware samples, and samples of household

8) Interviews conducted in Guangzhou, July 2006 and July 2008. 
appliances, and he can then choose. In my office, we discuss the quantity, the order, and the price, and when we have come to an agreement, I call my different suppliers, who deliver to me directly from the factory under a lead time that I also negotiate. The orders are often several dozen containers each time'. Mr. D employs around 50 Chinese in his trading agency split between the office and the warehouse. Mr. D's involvement in the production of goods exported to Africa has strengthened over the years and should soon extend to his home country. He is an archetype international trader, reinvesting as much in China (taking a stake in a factory set up in mainland China) as in Africa (owning houses in Lomé, Abidjan, and Dakar, buildings and a commercial center in Bamako).

As for the young individuals who are also taking part in the consolidation of these trading places, the majority of them have pursued higher studies outside their own country. Mr. A, ${ }^{9}$ a Ghanaian who opted to take a journalism course in England and then in Holland, chose to change direction for political reasons and took up commercial activities after having practiced in Ghana. Mr. B, ${ }^{10}$ a native of Futa Djalon in Guinea, left for New York in 1989 to pursue a higher degree in information technology. Convinced that he would not be able to draw full value from his engineering degree in Guinea because of the economic and political insecurity that reigned there, he set up a company in the United States to export computer equipment. There he benefited from social capital and technical abilities as well as from economic capital thanks to the support of an older brother who had emigrated to the Congo: 'I sell computer equipment bought here in China to American clients, clients from the Caribbean; Africans in the USA as well. I work by e-mail, fax, and telephone; I also go on trips, I have an office down there. In fact, I started to go to and fro between New York and Guangzhou in 2002. The first time, I came here for two months [From December 2002 to January 2003] and then I went back; afterwards I took a trip in March and then another one in August. It began to last longer and I set up shop here. Now, I am here more than I am in New York'.11

Other traders, like Mr. $\mathrm{H}$ and Mr. $\mathrm{L}^{12}$ have completed graduate studies in China. Having studied medicine in Algeria, Mr. H went back to his native Niger to become a veterinary inspector. After receiving a scholarship from the Chinese government to specialize in animal breeding genetics, he settled in

\footnotetext{
9) Interview in Guangzhou, July 2006.

10) Interview in Guangzhou, July 2006.

11) Interview with a Guinean trader in Guangzhou, July 2006.

12) Two interviews conducted in Guangzhou, July 2008.
} 
China. At the end of his studies, he decided to stay to export veterinary products and materials to the Maghreb, Africa, and Europe. Mr. L obtained an MBA in Canada and moved on to a PhD in China. At the same time he started up the export of Chinese goods bound for his home country, the Democratic Republic of Congo. These individuals combine special skills and have very few competitors in the niches they occupy: mastery of the Chinese language, a detailed knowledge of Chinese culture and local authorities, and connections in the consular and specific professional communities.

Fluency, mobility, and diversity characterize African migrants in the trading posts. Old nomadic merchants convert back to being traders after a few years. Or, conversely, traders abandon their offices; preferring to limit their fixed costs, they return to the itinerant trade. Still others, like Mr. L, use their mobile phone and take care of their business in the cafés of the tower blocks in the district of Xiao Beilu rather than in offices. Careers in sales are changing as circumstances dictate, depending on events and opportunities. Nothing is set in stone even if each event does not mechanically produce an alternative route or a turning point in the life of traders. Traveling and getting in touch with very different people and legislations thus leads migrants to show flexibility, malleability in their behavior, and to make links between their previous experiences and their current jobs.

\section{Traveling Traders: A Growing Feminine Representation}

Another figure, the traveling trader, is characterized by constant travel back and forth between Africa and Asia. Sometimes he or she is renamed visitor, commuter, or 'merchant in the bag,' even if the last expression does not mean he cannot transport large quantities and even whole containers. It is movement and spatial mobility that allows him to keep his role in this set. A traveler from Benin ${ }^{13}$ explained that moving to China six times a year does not prevent him from regularly traveling to Bangkok to source fabrics. Their business visa allows them to stay for up to three months. It is indeed the current hardening in the management of migratory flows that shapes trading. International migrants are increasingly turned into international storekeepers, and spatial mobility becomes a commercial strategy.

The traders' clientele remains predominantly African and male; it is composed of both 'circulating merchants,' consolidating the shuttle between the Asian trading posts (Bangkok, Hong Kong, and Guangzhou) and the African

13) Interview conducted in Bangkok, July 2008. 
markets, and of businesspeople placing their orders directly from their companies located in Africa, Europe, or the United States. The latter have become acquainted with the range of products offered by the traders, either during an initial prospecting trip or from the networks set up by these same traders in several African countries. The traders generally take care of the transport and transit operations as well as the customs clearance of the goods.

A recent trend is the feminization of the profession which is indicative of a more comprehensive transformation in international migrations (Rosanders 1991; Ebin 1995). Located in Paris, Marseilles, Las Palmas, Naples or in Bamako, Dakar, Conakry, Abidjan, Cotonou, Lusaka, or Dar es Saalam, African businesswomen - single, married, divorced, or retired from civil service - are forsaking in ever greater numbers the trading post of Dubai to come and find their supplies on the Asian markets. An old lady from Mali, dressed in loincloth (pagne) fabrics told us she commuted five times a year between Guangzhou, Bangkok, and Dubai to supply leather goods, shoes, gold-plated jewelry, and prayer mats for the small shop she runs in front of the main post office in Bamako. ${ }^{14}$ Two ladies from Tanzania encountered in the train between Hong Kong and Guangzhou were finishing their 'circuit,' having made their first purchases in Paris and in Italy the previous week. Accompanied by a Chinese translator, a Kenyan lady, a recent graduate in business management, came to join a group of traders and West African nomadic merchants sat at a table in a café in a tower of Tianxiu Building in Guangzhou. She was just starting out in the profession; this was her first trip to China. On the upper floors of the building, in the small inns, two ladies from Senegal described their respective journeys. ${ }^{15}$ Retired from Civil Service, one of them, originally from the middle valley of the Senegal River, had been to Guangzhou every three months for the last four years to procure office furniture and tiles. This was the only way for her to financially support her eldest son, a graduate who had emigrated to France. The second Senegalese woman, a Wolof speaker who had resided in the Canary Islands with her family for over 20 years, shifted her supply channels in costume jewelry ten years ago from the United States to China. This phenomenon of commercial shuttles which has been developing in Africa for about 20 years is also to be understood through the globalization of the labor force markets and the deterioration of working conditions in Sub-Saharan Africa. The rise of unemployment and the relegation of women to the background (divorced and repudiated) having already weakened families, people rushed to take advantage of makeshift

\footnotetext{
14) Interview with a Malian traveling trader in Bangkok, July 2008.

15) Interviews with three Senegalese traveling traders in Guangzhou, July 2008.
} 
livelihoods (in Senegal: 'système de débrouille'). Gradually, the demographic profiles of these women diversified: single and married women also rushed into a profitable trading activity which allowed them to gain a relative autonomy. Overall the last two years have witnessed the arrival of East-African saleswomen, often more successful than their fellow-countrymen at getting business visas. Chinese customs officers share the same sexist prejudices as their African counterparts, and are often convinced that the trading women will not take advantage of a tourist or business visa to emigrate (Lesourd 2006). These assumptions were confirmed through discussions with consular authorities and customs officers in several West African countries in which I stayed.

\section{Students and Adventurers}

In recent years, two other categories of migrants who by their very behavior disturb the settled African traders have appeared on the scene. The first is composed of students who have failed their academic careers in the PRC, and see interpreting and bargaining as exit routes. They arrived in the 1980s, often with a Chinese scholarship. Some of them were initially approached by African traders and Chinese officials during trade fairs in Guangzhou and its surroundings. ${ }^{16}$ The second group gathers people who venture into China with a view to reaching Europe or the United States. Some rely on their language or sporting skills; one case in mind is Mr. $\mathrm{D}^{17}$ from Nigeria who tried to make use of his sporting ability rather than his degree. He initially played football for a second division club but when his contract came to an end, his status became illegal. Only through his marriage to a European girl settled in China could he remain in Guangzhou, where he coached a young Chinese team. According to the Vice-President of the Congolese community of Guangzhou, the sports circuit eventually dried up: 'From 2002 to 2004 it was the craze but after that period the soccer players have left and those that stay don't know what to do.'18 Two African football players, passing through Bangkok and under contracts of employment in the United Arab Emirates, explained to me that whilst China had begun to recruit African basketball players, the Chinese sports authorities had not yet developed an interest in international soccer. These remarks confirm the research by Poli, Ravenel, and Besson on the career paths of African footballers in the mirror of globalization (2010). If the number of expatriate

\footnotetext{
16) Interviews in Hong Kong and Guangzhou, July 2008.

17) Interviews with a Nigerian footballer in Guangzhou, July 2006.

18) Interview conducted in Guangzhou, July 2008.
} 
players from Africa and America has strongly increased in recent years, their mobility is mainly focused towards Europe.

Others, dubbed feyemen - in reference to the trade expanded by Cameroonians in their country of origin - make use of trickery and fraud to take advantage of their temporary presence on Chinese soil while waiting for a possible departure to the West (Malaquais 2001). 'They came here to find an exit to Europe. It worked for a few months. Some could reach Europe but those who came after were stranded here.' ${ }^{19}$ In other words, the temporary location in China is a form of transit migration. The Congolese 'fathers' sons' as well as certain Burundian students who found themselves wandering around in Guangzhou in 2007 illustrate this point well. Stuck in China, they had hoped to move from Guangzhou since smugglers had previously operated in the area, enabling fellow countrymen to reach Europe or Canada. Such a lengthy route may seem odd, but it worked before being dismantled. Rumors, however, have lingered on, and Congolese migrants as well as others from Central Africa continue to flock to the Middle Kingdom.

Those who do not realize their 'plans' remain in groups and wander around in public spaces, making their differences salient. Gathered in groups, some carry beer and sit in the stairways of degraded buildings in the city's sinuous lanes. Often, they play billiards on the ground floor. Happy and talking loudly, a bottle in hand, they do not opt for discretion. Repeated repression by the municipal authorities has sent them further into smaller street lanes, away from the epicenter of the wholesale trade. This consumption expresses their desire to show what they consider as social success. Whereas they are seen locally as loiterers, they perceive themselves as adventurers 'in search of life.' As they revisit the world they claim to be adventurers, re-enchanting African mythologies to give meaning to their life projects beyond their experience of migration, in a society that increasingly excludes them. The adventure is not necessarily an unexpected, extraordinary event mixing danger and the pleasure of discovery. The adventurer does not exist solely through his actions, but also depends on what people say about him and how they say it. Whereas the feyemen have a high opinion of their own practices and compare the 'ripping off they commit to heroic acts, Chinese translators and the vast majority of African traders consider these adventurers to be immoral figures who damage the African trade (Bredeloup 2008).

19) Interview with a Nigerian trader in Guangzhou, July 2008. 


\section{Renewal Terms of Hospitality}

\section{Xiao Beilu: Ethnic Enclave or Global Trade District?}

Expanding the African trading posts requires certain conditions of hospitality to be brought together locally. Although Tanxiu Building located in the core of Xiao Bei was recently renamed from 'Yemen Building' in reference to its previous Arab occupants to 'African Tower,' it is not the only one to accommodate Sub-Saharan merchants. Fearing the constitution of an ethnic enclave caused by the influx of new traders and African itinerant merchants, the local authorities took drastic measures aiming at their dispersal in the city. In 2007 Tianxiu Building, a 35-storey building gathered 600 offices of which $70 \%$ were rented to African and Middle Eastern nationals. Its occupation rate declined to the benefit of the neighboring towers, along the Huanshi Middle Road, a key and 'structuring' artery located north-west of the city. By a ripple effect, other malls as well as Tao Ci Mansion, JinShan Elephant Trade Mall, and Overseas Trading Mall have been set up in the neighboring towers (Xiushan, Guolong, Yisheng Buildings...). Showrooms and offices are usually located on the upper floors of the towers, and freight services, customs clearance, and internet cafes on the ground floor or in adjacent streets, near hotels and restaurants catering for passing trade.

In our recent work, where conflicts over ownership of space were reported between Chinese and Africans, we however observed there to be a handover from Arab to Sub-Saharan migrants instead of a joint presence. A few African traders have gained access to commercial and residential areas used by Arab businessmen, but only after a time-lag of some years. Professional contacts were made between Tunisian, Moroccan, and Malian storekeepers sharing the French language and the same Muslim culture. North African businessmen gave advice to their Malian counterparts to spare them unpleasant surprises and sometimes provided them with suppliers' addresses. They introduced them to trading agencies acting as guides with small groups of itinerant merchants. The same phenomenon had already been documented in the historic center of Marseilles at the beginning of the 1980s, where Algerian and Tunisian storekeepers had helped the Senegalese to get a foothold in an old district abandoned by local storekeepers (Koné 1995; Bertoncello and Bredeloup 2004).

The Xiao Beilu district is often described by Chinese citizens, European journalists, and Chinese scholars as a ghetto or an 'African Town.' In fact, the situation is more complex. ${ }^{20}$ The concept of enclave expresses the idea

20) See the paper entitled 'Africa town à Canton,' Alternatives Internationales, $n^{\circ} 36$, septembre 2007 or the article written by Li, Xue, Lyons, and Brown (2007). 
of a strong spatial concentration of an ethnic, cultural, or religious minority in a given district. Though Guangzhou has the strongest density of African businessmen in the PRC, one cannot consider Baiyun and Yuexiu districts as enclosed zones. The African presence is strongly visible in these central places, with estimates obtained from officials of the African associations in Guangzhou putting the number of Sub-Saharan Africans settled more or less permanently at just under 20,000 in 2008 . But African residents are still in a minority in these districts. Unlike Dubai, where the owners of cargo companies (transit, harbor, and airport customs clearance) delegate the escort of buyers to 'small brothers,' in Guangzhou this activity is carried out by young Chinese. Indeed the labor legislation compels foreigners to favor the recruitment of national employees. It is in fact the visibility of the African visitors when they move during the day between the shops of the wholesalers and their hotel or when they relax in the public place at the end of the day which can lead to this impression of a strong African concentration. African visitors are in permanent contact with suppliers, hotelkeepers, and Chinese restaurant owners. Moreover, African traders settled in the capital of Guangdong maintain professional and sometimes marital relations with Chinese women. These links can mostly be identified in private spaces (offices and houses), but they are sometimes visible in cafés and cyber cafés in Tiaoxiu Building. These links exist even if they are rarely claimed by the African storekeepers. These discreet relations regulate the district's everyday life, and probably favor a better local and professional integration of the African traders.

\section{Africans in the Street: Subversion or Cosmopolitan Attraction?}

Taking passageways that weave their way up and down the towers, mobile phones screwed to their ears, African merchants move from one building to the next in search of the best deals after viewing the wholesale markets of Zhanxi, Liuha, or Baima. They criss-cross the malls from morning to evening. Women in African dress chat at a tower entrance before going off to prepare food in informal restaurants on the upper floors. Others hail taxis to transport bulky goods from one place to another. In 2006, during my first field trip, one encountered this same visibility of the African population, mostly Nigerian, in the public space around the Kanaan market (specialized in the jeans trade) and near the subway entrances in the Saniyanli district, further north. But they are not the only foreigners to bustle in these central places of the cheap international trade. We also met Pakistanis, Indians, Turks, Iranians, and Arabs there, only less visible. 
In 2007, an outdoor terrace set up at the foot of Jin Shan Elephant Trade Mall (Xiao Bei area) had been transformed by the African residents into a place of sociability and renamed Matonge in reference to a lively neighborhood of Kinshasa (Gaborit 2007). Some were talking over a beer late into the night, others watched video clips of their countries projected on walls, or even danced to the latest African hits. Meanwhile some residents (both Chinese and African) complained about the noise, but this lively place, locally renamed 'Chocolate City' or 'Little Africa' by taxi drivers nevertheless attracted a growing number of Cantonese attracted by the novelty. At nightfall, Chinese workers also take over the north side of the district of Xaio Bei, where small stores and cheap restaurants offer goods from around the world. It is a cheap and easy way to widen one's horizons, taking a break after work by looking at African dancers and listening to African music. Are they only onlookers? Short-lived links may well be formed between African and Chinese people in these festive, cosmopolitan spaces.

A number of Chinese residents have benefited economically from the arrival of the Arabic, Indian, and later African itinerant storekeepers by offering commercial infrastructures (specialized malls, stores, rent of offices, freight services, and restaurants) and hotel facilities. They understood the interest they had in maintaining good relations with this itinerant clientele. On the south side, in recent high-rise buildings, these arrivals brought about a relocation of the Chinese traders. There, owners seem less interested in welcoming these visitors, with the exception of those landlords who exploit the precariousness of the migrants and offer them poor-quality accommodation at high prices in the small buildings of the northern part of the district. Nevertheless, the Chinese media associate the African presence in these districts with an illegal installation. African residents try to fight this negative image by making a distinction between 'good' migrants and 'bad' ones.

Not all Africans make noise; only the latest arrivals do so. They're uneducated youngsters who are not looked after by their parents ... They drink beer all night and they prevent others from sleeping... They come here to trade but they realize they can't so they do something else. They enjoy themselves and have fun and at night they organize parties. ${ }^{21}$

The Congolese are noisy all night in Tianxiu, so it is only natural that the Chinese are annoyed. The Chinese appreciate when you are disciplined. Until seven years ago they admired us and now they hate us. Why? There is an Africa-phobia. Go to nightclubs and you'll see what it's like. There, there's noise all night long while the Chinese go to bed at $11 \mathrm{pm}$ and are up at $6 \mathrm{am}$ !... Groups of five or more are prohibited in China so they continue to party in apartments. You wouldn't believe how much noise they can make! ${ }^{22}$

21) Interview with a Nigerian trader in Guangzhou, July 2008.

22) Interview with a Nigerien trader in Guangzhou, July 2008. 
According to an already well-known procedure related to the close and the distant (Bastide 2000), some African traders accuse their unemployed 'brothers' of tarnishing their African reputation and they emphasize the mutual behaviors they share with the natives. Gradually perceived as a potential site of subversion by the municipal authorities, this terrace has been closed. ${ }^{23}$ However this intimidation has not exactly provided the desired effect. Indeed if the majority of young Africans left the places, some have taken over the urban environment of local passageways, sidewalks, stairs, curbs, and neighboring alleys and stay visible for the Chinese inhabitants. The police authorities have closed schools, places of worship in the surroundings (mosque and evangelist churches), ${ }^{24}$ and community restaurants that the Africans had informally set up in the apartments that they rented. Is this due to the fear of new ideas and practices or the fear of ethnic mixing? If these measures are difficult to understand, the African presence in Guangzhou definitely disrupts the Chinese authorities who are not accustomed to welcoming such 'distant' foreigners, taking over public places for use as private space and who also fear these places can become favorable for drug trafficking and money laundering. Yet meetings and cultural or religious events are forbidden in China unless the authorities are warned. The Africans learnt this to their cost and were not able to associate they wished. As a result of the pretext that gatherings in the same towers could lead to the formation of ethnic enclaves, the Chinese real estate companies are increasingly reluctant to rent their premises out to African traders. It is a well-known and efficient process used by a number of property developers and which is not specific to the Chinese authorities. One can cite the direct consequences when in July 2008 commercial premises previously occupied by African traders were taken over by their increasingly aggressive Chinese competitors. The former were asked to explore the surrounding neighborhoods, further north while others decided to leave the town and head for Yiwu, contributing in their way to the polarizing character of Xiao Beilu area. In addition

23) The local press mentions drug trafficking in these places, a point African informants commented on during my fieldwork: 'Ifyou are African, Black African, for Chinese policemen, you're selling drugs. It is their way of thinking. The policemen suspect and pick up all guys because of their color.' Between 2007 and June 2008, several hundreds of Africans were arrested for drug trafficking. I did not approach this question head on but obviously if Africans are involved in the business of drugs, they are not the only ones. Other foreign communities as well as the Chinese could feel equally concerned about such trafficking.

24) In the largest church of Guangzhou, the audience is over $90 \%$ African, mostly Nigerian. 
this can explain why African people seemed to be more discreet in public during my second visit. $^{25}$

\section{Further Competition}

If the visible but very limited African presence cannot lead to a mutation of Chinese labor markets, the hiring of Chinese staffs by African companies does however introduce a comparison of working conditions. African traders in Guangzhou tell us that they pay their Chinese employees two to three times more than those working for domestic firms. According to them, this practice has generated some responses from the Chinese government, which fears wage claims in a local context marked by an upsurge of social unrest. 'They are afraid that foreigners are opening the eyes of the Chinese.' Invariably similar formulas were used by most of our African contacts during our July 2008 interviews. Informal discussions started with some Chinese translators ended in more differentiating outcomes: if the African bosses have to recruit national employees and seem effectively to pay their employees better than the Chinese operators, the indicated salaries seem also overestimated. These direct data remain too imprecise and could not be checked without having access to payslips. Linked with the arrival of foreign traders and with the toughening of migration policies, new businesses emerged which aim at bypassing the law and coming close to mediation. Playing on regional autonomy, the Chinese head off to negotiate permits and residence visas for African traders in the least economically developed provinces. Fake visas, e.g. six months long, can also be bought from Chinese intermediaries for RMB19,000 (USD3,00o) in another province. Other niche markets include negotiating rents with unwilling or greedy landlords: 'Foreigners cannot live where they want and are forced to go to more expensive places. If you want to rent somewhere you do not go yourself, you send a Chinese for you to get a good price'. ${ }^{26}$ Once again, this figure is not unlike that of Middlemen Minorities, those intermediaries located in a foreign country who benefit from their transnational networks and interpersonal skills to position themselves on the register of negotiation, facilitating links between buyers and sellers.

25) One month after, more than 3,000 Nigerians were arrested because their papers were not in order and they were imprisoned. Someone died trying to escape the police (Daily Champion, August 11 2008). At the end of 2008, the sentencing to death of eight Africans accused of smuggling drugs in the PRC shook the African community and led also to an upsurge in police controls.

26) Interview with a Senegalese trader in Guangzhou, 2008 July. 
The new regulations adopted for alien migration on the eve of the 2008 Beijing Olympics Games, the rising cost of goods, and the currency inflation have caused an increased spatial movement of traders thus leading to a greater vulnerability. The increased police violence against internal and external migrants led African traders settled in Guangzhou to fall back on Bangkok, Jakarta, or Dubai, to continue on to Yiwu or to return to their families back home following the new government measures on visas. A lot of children came back home to start a school program in French that was not possible in Guangzhou. It is also what explains why they were less visible in public places in 2008 .

The African traders are not surprised by this tightening that they try to understand: 'It is not only the Olympics but also China which is closed because it must deal with people who wake up'. ${ }^{27}$ According to our informants, nearly half of Sub-Saharan nationals settled in Guangzhou and the surrounding area left the region in 2008 because of repeated checks on visas. They did not wish to integrate into China's mainstream society in spite of their long stay in China. Similarly visitors were forced to return to their home countries to apply for visa renewal since they did not have enough time to conclude their business, whereas until spring 2008, they managed to move on to Hong Kong or Macao. It was less expensive. 'That is what hurts the most. You are a businessman, you are supposed to leave the country by the 19th of the month; you leave millions here. You go to the immigration service to extend your stay for a week and they throw your passport in your face; it is unbelievable!'28 It naturally becomes increasingly difficult in a shorter time frame to renegotiate over goods when they are of bad quality. It is not uncommon that wholesalers leave without orders when their visa has expired. We can understand in these conditions that visitors prefer to go to stock up in Dubai where the legislation is sharply more flexible.

In the People's Republic of China, the latest arrivals are facing saturation of the labor market. The remaining niches are very limited and they have to perform the most precarious, dangerous, and less legal activities. In Guangzhou, the Congolese are the very latest in a heavily congested market and they struggle in vain to be the interface between Chinese factories and African travelers. This niche, which was already largely held by Africans awaiting the opening of an office, is progressively controlled by Chinese intermediaries. Due to their work with an African clientele, these Chinese assess their needs better and sometimes arrange bigger assets than the African wholesalers to negotiate

27) Interview with a Guinean trader in Guangzhou, 2008 July.

28) Interview with a Congolese trader in Guangzhou, 2008 July. 
interesting contracts with Chinese industrialists. Citizens of Democratic Republic of the Congo become increasingly dependent on money orders that their parents back home are willing to send them when they do not try their hand at selling pirated African music. The majority of Congolese migrants met in Guangzhou were not traders before but students or unemployed people. Consequently they were badly prepared to compete with hardened traders in a saturated market. Some of them work in hair salons in the malls for African customers; others try to be guides for new itinerant visitors. The fierce competition between fellow countrymen leads to a dropping out of those migrants with the least social and economic capital.

More widely what can we tell about interactions existing between the African and Chinese traders? Are they systematically built on a model of competition and tensions or do they result in more harmonious exchanges? At first African and Chinese traders often encounter the same problems as do Chinese sellers and foreign buyers. The first ones hesitate to deliver the goods before receiving payment and try to decrease the quality of the product or to increase the delivery deadlines when they work for a long time with the same intermediaries. The second ones try hard to delay payment with the traders while these last ones have to take care quickly of the transport and of the customs clearance of containers. African buyers who come can leave Guangzhou without paying. African buyers who stayed in Africa can also defer their payment. One of the main differences between Chinese and Africans traders perhaps explains the fact that the first ones are better armed to set up bribing practices with the Chinese Customs while the second ones are better placed to make the goods clear through Customs when they arrive on the African continent.

It was said that some Africans established joint-ventures with Chinese associates in specific markets but I was not able to check this personally. The Chinese women married to Africans I met did not seem to be involved in the activities of their husbands. What appears clear is that some people have to continuously innovate to keep their place and their business volume. Nothing seems acquired. The products which pleased yesterday flooded the African market, and the traders have to be renewed and surround new markets, being on the lookout for the new expectations or tastes of consumers. In 2008 building and bathrooms materials seemed very appreciated and looked for by African visitors. In the same way the Chinese traders discover and determine better and better the needs and African fashions, the African traders investigate new trails to adapt their business to this new competition. Some of them go to factories to buy back at a better price unsold articles. Others negotiate with the Chinese factories the manufacturing of products of better quality 
having already canvassed the clientele in Africa. But the growing presence of Chinese merchants in African countries could change the economic order.

\section{Conclusion}

To remain sustainable the African trading post combines and articulates several market places in the course of political and economic imperatives. To operate in Asia, the African trading post requires two groups of actors: traders established in the host country and resellers who move between the market places. The former provide the market places with products manufactured or processed in adjacent economic regions towards the latter, who in turn supply customers located in other continents. The African trading post also means that sedentary traders are really the bridgehead of Sub-Saharan migration negotiating their settlement within civil society and adapting to the local conditions of hospitality offered to them.

Contrary to Bangkok and Hong Kong, in Guangzhou, Chinese nationals have begun to take over the African business places and to stand out as middlemen, representing the Chinese factories directly to the visiting businessmen. Under these conditions, African migrants must sharpen their strategies. They are forced to sell new or end-of-line products to develop new occupational niches and can sometimes find new breath in mediation. Yet, factors such as the recent tightening of migratory policies, the increase of the Yuan along with the cost of living, and the rise of Chinese traders in Africa are making foreign economic successes in China more and more uncertain. The African trading post is threatened at its foundations. The most powerful traders in Guangzhou know that their future is compromised in the long term even if their trading agencies seem to be stabilized. Hardened by the migratory experience, they understand once they have been initiated what is covered by the restrictive measures taken by Chinese authorities: 'The Chinese man is clever; he is someone who lets you come to him. He watches you for a while and when he has understood he sends you away and takes your business in his name'. ${ }^{29}$ The best advised Africans, therefore, are simply trying to gain time. They put their money in their own country and in other African countries. They canvass elsewhere in Asia and increase their efforts towards their governments to organize their return home as well when it is the time to. Some of them also plan to politically invest in their country of origin. Solidarity between Africans is

29) Interview with a Guinean trader in Guangzhou, July 2008. 
more relevant in this context. All attempts to establish a federation of African traders in order to protect themselves against Chinese competition have failed. Besides the Chinese authorities, the internal debates also prevented its implementation. Now everyone, alone or with their family, is working on their own future. As for the poor, they continue on their way towards less stringent places or turn back, effecting spatial mobility inside the city and between the cities in a survival strategy. Others prefer to close their eyes, hoping for a miracle, any opportunity, sometimes looking for refuge in an imaginative world.

\section{References}

Agier, Michel (1983) Commerce et sociabilité. Les négociants soudanais du quartier zongo de Lomé (Togo), Paris, Orstom.

Bastide, Roger (2000) Le proche et le lointain, Paris, Harmattan.

Bertoncello, Brigitte (2009) 'Les Chungking Mansions à Hong Kong : tour de Babel africaine dans un quartier d'affaires en rénovation' in La Chine et l'Afrique: regards historiques, dynamiques spatiales et mobilités croisées, INALCO, Paris, 12 June 2009.

Bertoncello Brigitte and Bredeloup, Sylvie (2004) Colporteurs africains à Marseille. Un siècle d'aventures, Paris, Autrement.

- (2007) 'The emergence of new African trading posts in Hong Kong and Guangzhou,' China Perspective, 218: 94-105.

Bodomo, Adams B. (2006) Cultural and linguistic parallels between Africa and China: the case of some West African and Southern Chinese societies, Paper read at the 3 rd roundtable discussion on African studies, University of Hong Kong, May 25th.

- (2010) 'The African trading community in Guangzhou; an emerging bridge for Africa-China relations,' China Quaterly, 2 (3): 693-707.

Bonacich, Edna (1973) 'A Theory of Middleman Minorities,' American Sociological Review, 38 (5): 583-594.

Braudel, Fernand (1949) La Méditerranée et le monde méditerranéen à l'époque de Philippe II, Paris: Colin, 2 tomes.

Bredeloup, Sylvie (2007) La Diams'pora du fleuve Sénégal, Paris: PUM Toulouse, IRD.

- (2008) 'L'aventurier, une figure de la migration africaine,' Cahiers internationaux de Sociologie, CXXV (2) juillet-décembre: 281-306.

Cohen, Abner (1969) Custom and Politics in Urban Africa. A Study of Hausa Migrants in Yoruba Towns, London: Routledge \& Kengan.

- (1984) Custom and Politics in Urban Africa. A study of Hausa migrants in Yoruba towns, Routledge (first published by Routledge \& Kegan Paul in 1969).

Ebin, Victoria (1995) 'Women's Saints and Strategies: the Expanding Role of Senegalese Women in International Trade,' Mondes en développement, 91 (23): 113-115.

Gaborit, Marie (2007) Les stratégies d'acteurs chinois et leur rôle dans le développement de la coopération sino-africaine. Les cas du Sénégal et de la Mauritanie, mémoire de Master 2, Institut français de géopolitique, Université Paris 8. 
Gemdev (1997) États, politiques publiques et développement en Asie de l'Est, Paris: Karthala.

Hill, Poly (1966) 'Landlords and Brokers. A West African Trading System,' Cahiers d'Études Africaines, VI (3), no. 23 .

Izraelewicz, Erik (2005) Quand la Chine change le monde, Paris: Éd. Fasquelle \& Grasset.

Kone, Daouda (1995) 'Noirs-Africains et Maghrébins ensemble dans la ville,' Revue Européenne des Migrations Internationales, 11 (1): 99-114 p.

Lesourd, Céline (2006) Au bonheur des dames, femmes d'affaires mauritaniennes de nos jours, thèse de sociologie, EHESS, Paris.

Li Zhigang, Xue Desheng, Lyons Michael and Brown, Alison (2007) Ethnic Enclave of Transnational Migrants in Guangzhou: a case study of Xiaobei, International Conference of Chinas Urban Land and Housing in the 21st Century, 13-15 Dec, Hong Kong, $13 \mathrm{p}$.

Lin Yu (2006) Yiwu : le carrefour du made in China, Outremer, 15: 187-193.

Malaquais, Dominique (2001) 'Arts de feyre au Cameroun,' Politique africaine, 82: 101-118.

Pliez, Olivier (2007) 'Des jeans chinois dans les rues du Caire ou les espaces discrets de la mondialisation,' Mappemonde, 88 (http://mappemonde.mgm.fr/numı/articles/arto7404.html).

Poli Raffaele, Ravenel Loïc and Besson, Roger (2010) Demographic Study of Footballers in Europe / Etude démographique des footballeurs en Europe, Neuchâtel: CIES.

Rigg, Jonathan (2003), 'Exclusion and Embeddedness: The Chinese in Thailand and Vietnam,' in Laurence J.-C. Ma \& Carolyn L. Cartier, (eds.), The Chinese Diaspora: Space, Place, Mobility and Identity, Lanham: Rowman \& Littlefield.

Rosanders, E. Eva (1991) Women in a Borderland: Managing Muslim identity where Morocco meets Spain, Dept of Social Anthropology, Stockholm: Stockholm University.

Tarrius, Alain (1995) 'Naissance d'une colonie: un comptoir commercial à Marseille,' Revue Européenne des Migrations Internationales, 11: 21-52. 